\title{
Experience in the Use of Human Recombinant Erythropoietin (rHuEPO) in Cancer Patient with Anemia
}

\author{
Karmel L.Tambunan, Aru Sudoyo, A.Harryanto Reksodiputro*
}

\begin{abstract}
Abstrak
Anemia pada penderita kanker dapat disebabkan berbagai faktor seperti toksis sitostatika pada sumsum tulang, defisiensi besi, asam folat, hemolitik dan perdarahan. Anemia ini sering disertai kadar eritropoitin yang relatif kurang. Atas dasar kenyataan tersebut di atas diharapkan pemberian eritropoietin pada penderita kanker akan dapat lebih merangsang eritro-poiesis dan menaikkan hemoglobin. Pasien yang diteliti yaitu penderita kanker yang sedang mendapat kemoterapi disertai anemia, dan penyebab anemia bukan karena hemolitik, defisiensi besi, defisiensi asam folat dan defisiensi $B_{12}$. Pasien yang diteliti terdiri dari 1 kasus Ca nasofaring, 2 kasus limfoma malignum dan 2 kasus multiple myeloma. Pasien diberi rHuEPO $150 \mathrm{iwkg}$, subkutan 3 kali seminggu, selama $16 \mathrm{ming}$ gu. Dilakukan pemeriksaan hemoglobin $(\mathrm{Hb})$ dan hematokrit $(\mathrm{Ht})$ tiap minggu dan pada minggu ke-12 ditemukan kenaikan $\mathrm{Hb}>2 \mathrm{~g} \%$ dan $H t>6 \%$ pada 4 kasus (80\%) dan pada satu kasus walaupun kenaikan $\mathrm{Hb}<2 \mathrm{~g} \%$ tetapi menjadi bebas dari kebutuhan transfusi. Pemberian rHuEPO seperti tersebut di atas dapat meningkatkan hemoglobin penderita kanker dengan anemia.
\end{abstract}

\begin{abstract}
Anemia in cancer patients can be the result of a variety of factors, often in combination. The chemotherapy-related myelosuppression is logically the main cause, but other conditions sometimes prevail, such as iron or folate deficiency, hemolysis, bleeding, or, as mentioned before, the combination of the above. Known as anemia of cancer or chronic disease, it is heralded by the disturbance of iron utilization and, recently, found to be accompanied by low erythropoetin levels. It is with the latter condition in mind that we have undertaken a study to assess responsiveness of the anemia of cancer to erythropoetin, in this case the human recombinant erythropoetin $(r H u E P O)$. Five cancer patients with varying types of cancers who have undergone chemotherapy were recruited, and received rHuEPO $150 \mathrm{iu} / \mathrm{kg}$, thrice weekly subcutaneously for a period of 16 weeks. Hemoglobin levels and hematocrit were monitored and at 12 weeks was noted an increase in hemoglobin levels by more than $2 \mathrm{~g} / \mathrm{dl}$ and hematocrit measurement by more than $6 \%$ in 4 cases (80\%). One case had increases less than the aforementioned but was made transfusion-free. We conclude that rHuEPO has an impressive hemoglobin-increasing effect.
\end{abstract}

Keywords : erythropoietin, anemia, ancer patient.

Anemia is a problem in patients with advanced cancer. Blood transfusion may be required in many of these patients, particularly those undergoing chemotherapy. Anemia in cancer maybe multifactorial in etiology and can be caused by a variety of conditions, among these are, i.e., iron or folic acid deficiency, hemolysis or bleeding. In the cancer patient receiving chemotherapy, the anemia can be aggravated by the effects of cytostatic-related myelosuppresion.

Generally, the type of anemia in cancer patients is of the chronic disorder type, ${ }^{1}$ characterized by serum

\footnotetext{
* Department of Medicine, Faculty of Medicine University of Indonesia / Dr. Cipto Mangunkusumo Hospital, Jakarta, Indonesia
}

level of endogenous erythropoietin (EPO) that are inappropriately low for the degree of the anemia, a blunted EPO response to hypoxia and low red blood cell production. The concentration of erythropoietin in the serum cancer patients is lower that expected compare to patients with iron deficiency anemia. ${ }^{2}$

Several studies groups have reported that recombinant human eritropoietin ( $\mathrm{HH}$ HPO) is able improved anemia in cancer patient. ${ }^{3}$

These early observations led to the conclusion that rHuEPO could be beneficial for cancer patients with anemia. The aim of this study is to evaluate the efficacy of of the use of rHuEPO in anemic cancer patients undergoing chemotherapy. 


\section{MATERIALS AND METHODS}

The study design will be an open label, non comparative evaluation of the eficacy and safety of subcutaneous rHuEPO administration in patient with anemia secondary with malignancy been treated by cyclic chemotherapy. Patient were enrolled in the study if they fulfil the inclusion criteria.

Criteria of cancer patients included in the study were non leukemia malignancy; hemoglobin $\leq 10,5 \mathrm{~g} / \mathrm{dl}$; iron, folate, B12 deficiency, hemolysis and bleeding ruled out as causes of anemia; patient still undergoing chemotherapy; no acute illness in the last 7 days; no radiotherapy in the last 30 days; life expectancy of 6 months or more; performance score of $0,1,2$, or 3,7 (WHO performance status); informed consent.

The patients underwent complete physical and laboratory examinations, which included hemoglobin, hematocrit, reticulocyte count, WBC, platelet count, ureum, creatinine, serum iron, total iron binding capacity, glucose, total protein, folic acid, B12, Coombs test, stool hematest, and prothrombin time.
Those eligible for study were started on 150 units per $\mathrm{kg}$ bodyweight of recombinant human erythrpoietin (rHuEPO) three times a week. The patients were then monitored with weekly examinations of hemoglobin, hematocrit, and reticulocytes. Side effects, if present, were noted. A response was defined as an increase in hemoglobin concentration of at least $2 \mathrm{~g} / \mathrm{dl}$ within 12 weeks, or increase in hematocrit by more than 6 percent in 12 weeks.

\section{RESULTS}

The trial was started in August 1993. Five cases were able to be included in the study, consisting of 1 case with nasopharyngeal cancer stage III undergoing chemotherapy with platinum and epirubicin, 2 cases of non-Hodgkin lymphoma, both stage III, at that time on the $\mathrm{CHOP}$ chemotherapy regimen, 2 cases of multiple myeloma, at stages II and IIIA, respectively, and who were receiving melphalan and prednison. One of the multiple myeloma cases was requiring packed red cell transfusions every month (Table 1 and Figure 1-6 showed response to treatment with rHuEPO).

Table 1. Response to rHuEPO in 5 cases of anemic cancer patients undergoing chemotherapy

\begin{tabular}{|c|c|c|c|c|c|c|c|c|c|c|c|}
\hline \multirow{2}{*}{\multicolumn{2}{|c|}{ Cases }} & & \multicolumn{9}{|c|}{ Weeks } \\
\hline & & & 0 & 2 & 4 & 6 & 8 & 10 & 12 & 14 & 16 \\
\hline \multirow[t]{2}{*}{1} & $\begin{array}{l}\text { Ca Nas female } \\
35 \text { years }\end{array}$ & $\mathrm{Hb}$ & 8.8 & 10.2 & 12.4 & 11.6 & 11.5 & 12.5 & 13.8 & 12.2 & 14.4 \\
\hline & old & $\mathrm{Ht}$ & 27 & 31 & 37 & 35 & 35 & 38 & 42 & 36 & 43 \\
\hline \multirow[t]{2}{*}{2} & $\begin{array}{l}\text { LNHa female } \\
21 \text { years }\end{array}$ & $\mathrm{Hb}$ & 9.6 & 10.5 & 11.5 & 10.7 & 12.2 & 10.2 & 12.6 & 11.0 & 9.6 \\
\hline & old & $\mathrm{Ht}$ & 29 & 32 & 35 & 32 & 38 & 31 & 38 & 34 & 29 \\
\hline \multirow[t]{2}{*}{3} & $\begin{array}{l}\text { LNH female } \\
30 \text { years }\end{array}$ & $\mathrm{Hb}$ & 8.2 & 10.2 & 11.2 & 10.8 & 12.5 & 13.2 & 13 & 13.2 & 13.4 \\
\hline & old & $\mathrm{Ht}$ & 25 & 30 & 34 & 33 & 38 & 39 & 38 & 39 & 40 \\
\hline \multirow[t]{2}{*}{4} & $\begin{array}{l}\text { MM female } \\
62 \text { years }\end{array}$ & $\mathrm{Hb}$ & 8.9 & 10.7 & 11.2 & 12 & 11.6 & 12.4 & 14 & 12.8 & 13.5 \\
\hline & old & $\mathrm{Ht}$ & 26 & 32 & 34 & 36 & 35 & 38 & 42 & 39.6 & 41 \\
\hline \multirow[t]{3}{*}{5} & $\begin{array}{l}\text { MM female } \\
68 \text { years }\end{array}$ & $\mathrm{Hb}$ & 8.0 & 7.0 & 8.0 & 7.8 & 8.2 & 7.2 & 9.0 & 9.3 & 9.8 \\
\hline & old & $\mathrm{Ht}$ & 24 & 20 & 24 & 23 & 24 & 21 & 26 & 28 & 27 \\
\hline & Mean & $\begin{array}{l}\mathrm{Hb} \\
\mathrm{Ht}\end{array}$ & $\begin{array}{l}8.7 \\
26.2\end{array}$ & $\begin{array}{l}9.7 \\
29\end{array}$ & $\begin{array}{l}10.6 \\
32.8\end{array}$ & $\begin{array}{l}10.1 \\
31.8\end{array}$ & $\begin{array}{l}10.8 \\
33.6\end{array}$ & $\begin{array}{l}10.8 \\
33.4\end{array}$ & $\begin{array}{l}12.2 \\
37.2\end{array}$ & $\begin{array}{l}11.7 \\
351\end{array}$ & $\begin{array}{l}9.8 \\
36\end{array}$ \\
\hline
\end{tabular}

Ca Nas: Cancer Nasopharynx, LNH : Limfoma Non Hodgkin, MM : Multiple Myeloma 


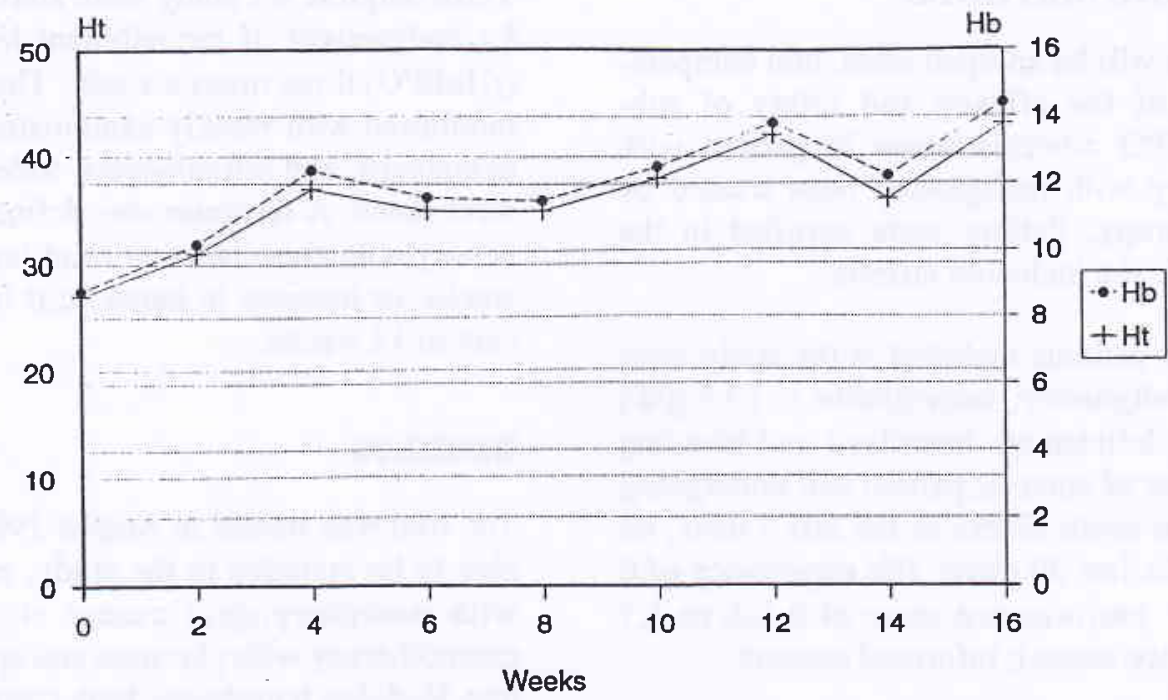

Figure 1. Case no. 1, female, 35 years old, Cancer Nasopharynx

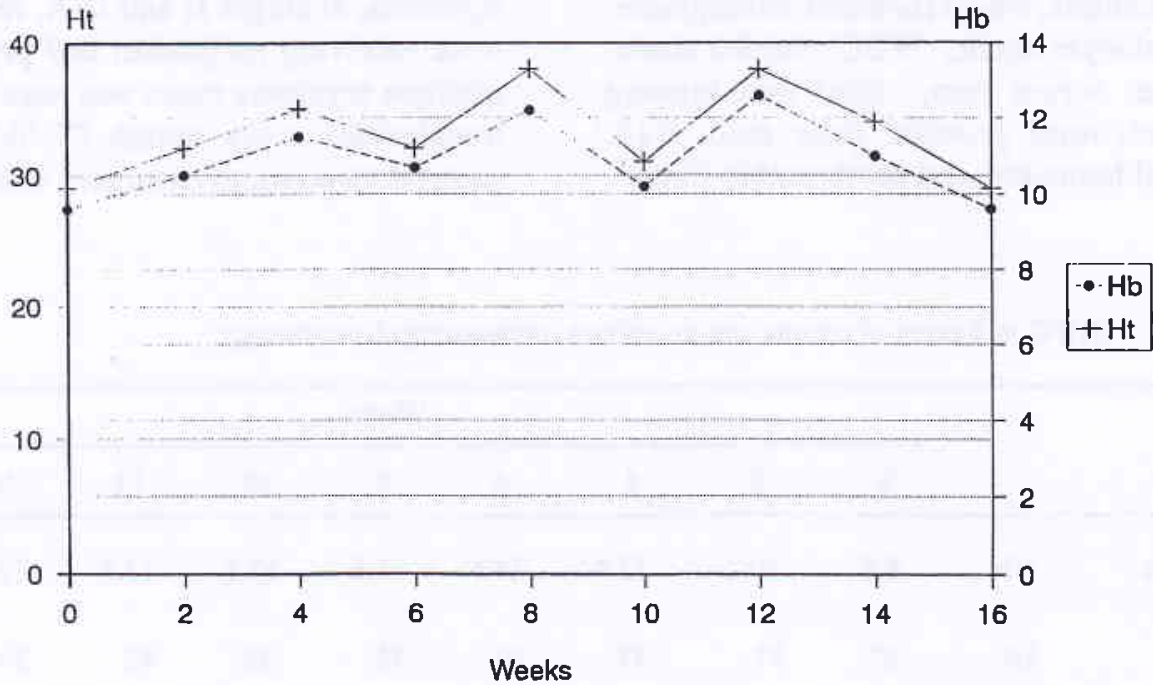

Figure 2. Case no. 2, female, 21 years old, Limfoma non-Hodgkin

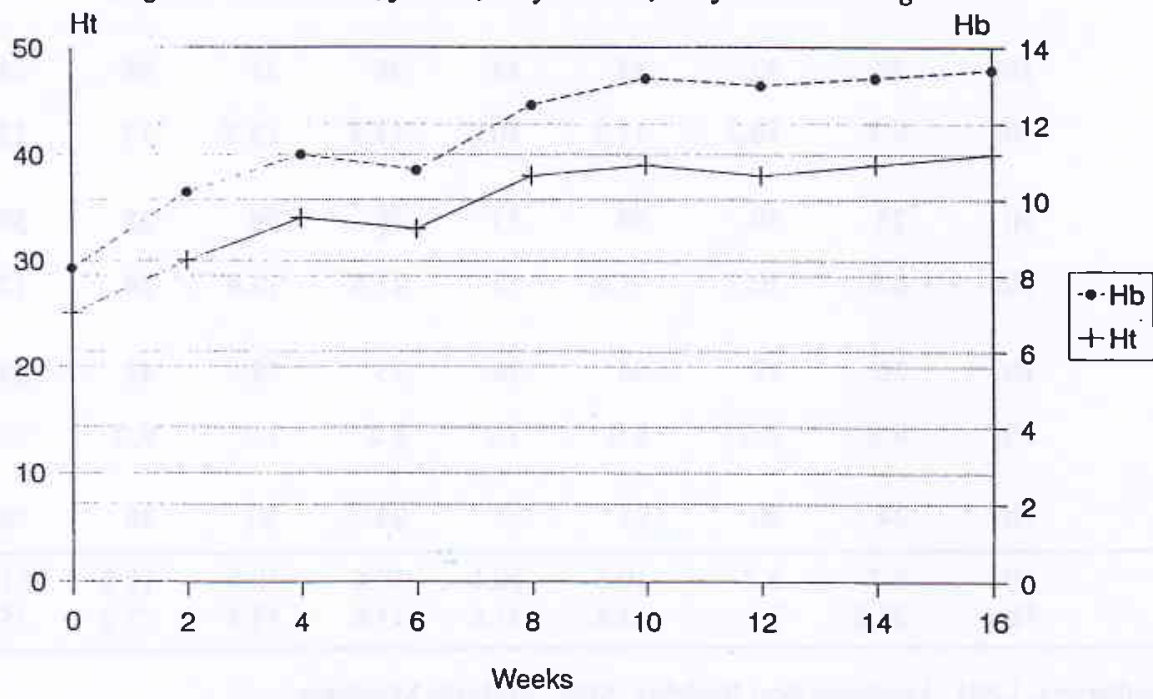

Figure 3. Case no. 3, male, 30 years old, Limfoma non-Hodgkin 


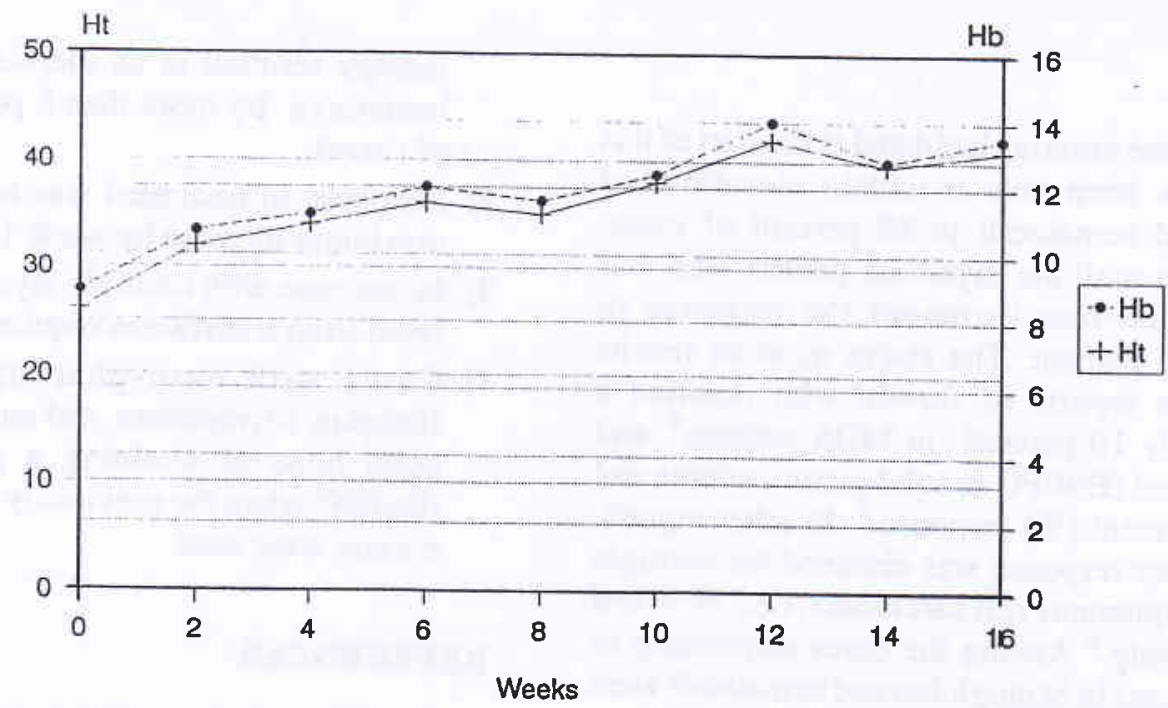

Figure 4. Case no. 4, male, 62 years old, Multiple Myeloma

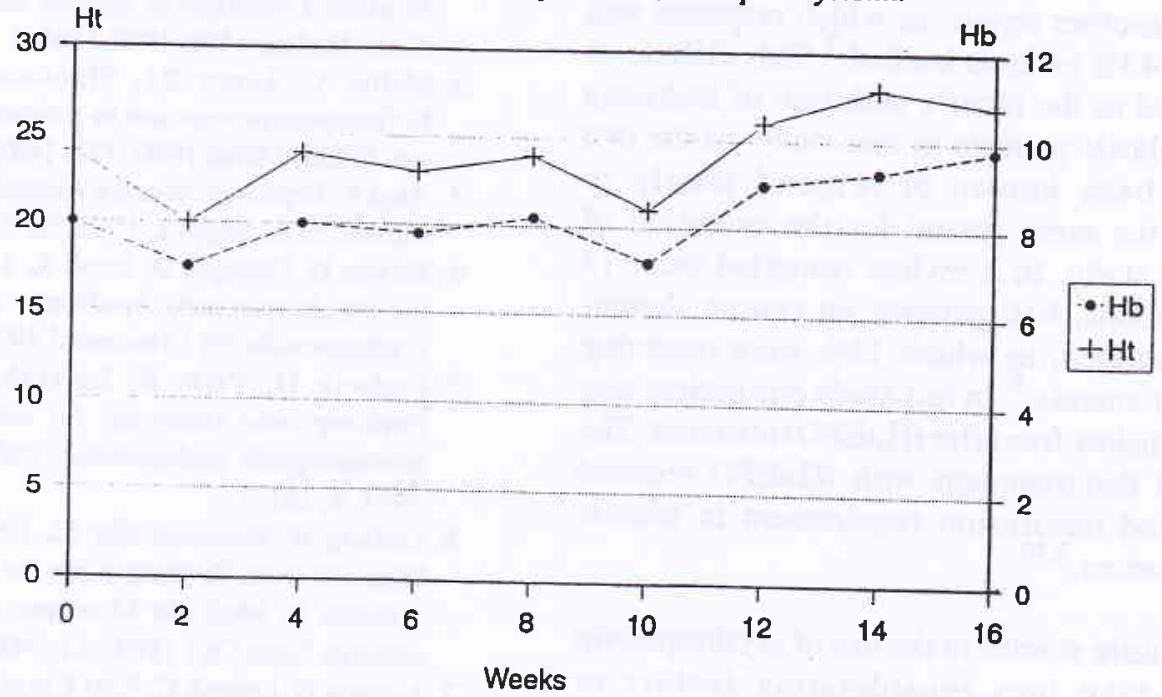

Figure 5. Case no. 5, male, 68 years old, Multiple Myeloma

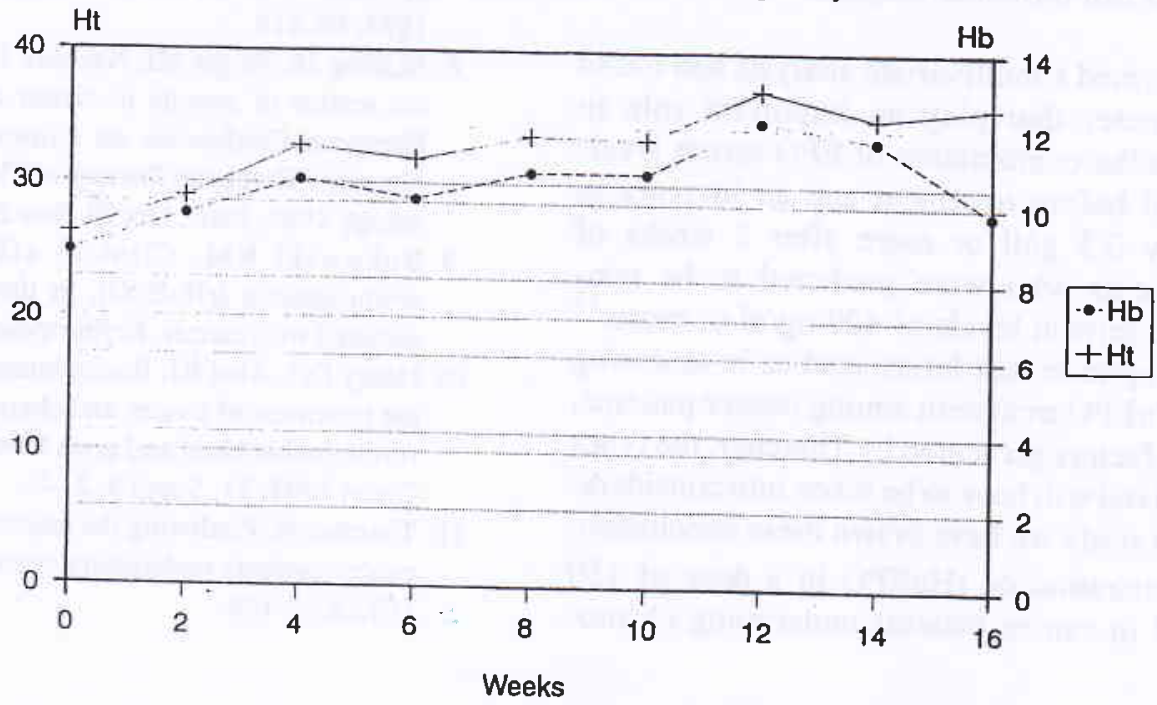

Figure 6. Mean $\mathrm{Hb}, \mathrm{Ht}$, from 5 cases 


\section{DISCUSSION}

Using the response criteria elucidated at the start of this study, we have been able to obtain elevations of hemoglobin and hematocrit in 80 percent of cases. Inclusion of the multiple myeloma patient who was made transfusion-free increased the response to rHuEPO to 100 percent. The above mention results differ from the reports of Bowen who reported a response of only 10 percent in MDS patients ${ }^{4}$ and Ludwig who used rHuEPO in solid tumor patients and elicited a 50 percent $(\%)$ response. ${ }^{5}$ In other reports, however, a better response was obtained for multiple myeloma and squamous cell carcinoma, i.e., $79 \%$ and $75 \%$, respectively. ${ }^{6}$ Among the cases responding to rHuEPO, increases in hemoglobin and hematocrit were actually seen by the second week. This finding was different from another report in which response was elicited in only $43 \%$ patients studied. 7 This difference can be attributed to the latter's inclusion of leukemia and myelodysplastic patients in that study, as the two entities have been known to respond poorly to erythropoetin, the same reason for the exclusion of patients in our study. In a review compiled from 12 medical institutions, 616 patients on cancer chemotherapy were studied, in which $12 \%$ were receiving transfusions for anemia. ${ }^{8}$ In this study one patient was rendered transfusion-free after rHuEPO treatment. The others reported that treatment with rHuEPO reduced both anemia and transfusion requirement in anemic patients with cancer. 9,10

It seems that future studies in the use of erythropoietin will have to take into consideration factors or parameters that can influence response.

Thatcher performed a multivariate analysis and found that the parameter that play an important role in predicting was the combination of EPO serum levels of $100 \mathrm{mIU} / \mathrm{ml}$ before treatment and an increase in hemoglobin by $0.5 \mathrm{~g} / \mathrm{dl}$ or more after 2 weeks of treatment. Patients who were predicted to be nonresponders had ferritin levels of $400 \mathrm{ng} / \mathrm{nl}$ or more. ${ }^{11}$ We are of the opinion that future studies in assessing response of rHuEPO treatment among cancer patients, aside from the factors presented by Thatcher, the types of cancer involved will have to be taken into consideration. From this study we have drawn these conclusion:

1) The administration of rHuEPO in a dose of 150 $\mathrm{mg} / \mathrm{kg} \mathrm{BW}$ in cancer patients undergoing chemo- therapy resulted in an increase $\mathrm{Hb}>2 \mathrm{~g} / \mathrm{dl}$ and hematocrit by more than 6 percent (in 80 percent of cases).

2) Response to treatment was noted at week 2 with maximum increase by week 12 .

3) In one case with multiple myeloma the patient was freed from transfusion requirement.

4) Cases with naso-pharyngeal cancer, nonHodgkin's lymphoma, and multiple myeloma have good hope of attaining a good response with rHuEPO when the previously mentioned inclusion criteria were used.

\section{REFERENCES}

1. Bun HF. Anemia associated with chronic disorders. In Harrison's Principle of Internal Medicine $11^{\text {th }}$ edition. New York: McGraw Hill 1987.1504-5.

2. Miller C, Jones RJ, Plantodasi's et al. Decreased Eryhtropoietin response in patients with the anemia of cancer. N Eng J Med 1990, 322, 1689-92.

3. Abel R. Erythropoietin for Anemia in Cancer Patient : Eur $\mathbf{J}$ Cancer 29 A. Suppl 2, 1993, 52-8.

4. Bowen D, Culligan D, Jacob A. The treatment of anemia in the myelodysplastic syndrome with recombinant human erythropoietin. Br J Haematol 1991; 77:419-33.

5. Ludwig H, Frizt E, Leitgeb C, Krehner $M$ et al. Erythropoietin treatment for chronic anemia of selected hematological malignancies and solid tumors. Ann Onc 1993, 4, 161-7.

6. Ludwig H, Petcherstorfer M, Leitgeb C, Frizt E. Recombinant Human Erythropoietin for the trreatment of Chronic Anemia in Multiple Myeloma and Squamous Cell Carcinoma. Stem Cell 1993.; 11: 348-55.

7. Ludwig H, Leitgeb C, Frizt E et al. Erythropoietin Treatment of Chronic Anemia of Cancer. Eur J Cancer 29A. Suppl 2, 1993, S8-S12.

8. Skilling JR, Roger MI, Nabolitz JM et al. An epidemiological review of anemia in cancer chemotherapy in Canada. European Conference on Clinical Oncology and Cancer Nursing / European Society of Therapeutic Radiologic Oncology 1995, Paris, Oct 29-Nov 2.

9. Bukowski RM. Clinical efficacy of recombinant erythropoietin (rHuEPO), in the treatment of anemia associated with cancer. Eryhtropoiesis 1994, 5, 108-14.

10. Henry DH, Abel RI. Recombinant human eryhtropoietin in the treatment of cancer and chemotherapy induced anemia, result double blind and open label follow up studies. Semin Oncol 1994, 21, Suppl 3, 21-8.

11. Thatcher N. Predicting the response to rHuEPO in anaemic cancer patients undergoing chemotherapy . Erythropoiesis 1995;8:99-108. 